\title{
Lifestyle Audit and Fighting Against Corruption: Evidence from Nigeria
}

\author{
Olaoye, Azeez Ayoola \\ Accounting Department, Ekiti State University \\ Olaoye, F. Oladipupo \\ Accounting Department, Ekiti State University
}

\begin{abstract}
Corruption is a global pandemic that can destroy the economy of any nation if care is taken. This study therefore examined lifestyle audits (LSAs) and fighting against corruption (FAC). This study adopted a survey research approach and employed primary data. A purposive sampling technique was used to draw the samples of 241. This study used bar chart, general linear and regression models to analyze the data gathered. Findings from this study showed that the estimated P-value of $000>0.01$ significant level. This study revealed a complete demand for the application of LSAs in Nigeria for FAC. This study recommended that government of any country including Nigeria that may wish to apply LSAs for FAC should amend their existing legal frameworks to permit full operation of LSAs during the investigation, arrest and trials of any corrupt suspect. The outcomes of this study could appeal to government, educational regulators and the accounting professional bodies world-wide on the need to incorporate the studies of lifestyle auditing into the curricula
\end{abstract}

Keywords: Lifestyle audits, fight against corruption

DOI: $10.7176 /$ RJFA/12-7-04

Publication date: April $30^{\text {th }} 2021$

\section{I.0 Introduction}

Globally, corruption is a disease that has the potentiality of destroying any country's economy if not arrested. The wide spread of the entrenched corruption can discourage foreign investment and damage the economy of any nation (Kola. 2018). Corruption is a growing phenomena that has negative impact on the world's economy especially Nigeria (Akenbor \& Ogbogbomeh, 2013). Nigeria is experiencing economic crisis due to political corruption which has caused negative effects on the poor. Many government officials corruptly diverted the public resources for private use. Payment for undelivered services, contracts not executed, ghost workers and over-invoiced supplies are the common practices nowadays. Nigeria is still worst economically as more than two-third of her people still remained poor due to the menace of corruption and other financial crimes. The rampant of corruption forced the citizens to voice out their frustrations through the ballot system in 2015 resulting in an incumbent president losing an election in Nigeria's history (Stober, 2019). Over time in Nigeria, various measures put in place to tackle corrupt practices end up with little result as the people of the country cannot absolutely enjoy the dividend of democracy. However, Nigeria needs total changes in the ways corruption cases are being handled by applying lifestyle audit as an antidote. Besides that, statutory audit (SA) in Nigeria is not capable of rooting out corruption due to its expectation gaps and the scope limitation imposed by the relevant Acts which can be overcome through lifestyle audits because the objectives of lifestyle audits are precisely to detect unreported income, unjust self enrichment, and the fight against corruption, money laundering, financial frauds, among others.

A review of literature in this study's area such like Daysh and Exley (2000); Ainsworth (2001); Norbert (2007); Jason (2007); Bekerian and Jackson (2007); Andre (2009); Gillespie (2014); Sam and Tim (2016); Munjeyi and Mujuru (2018); Kola (2018)Ngumbi (2019) and a host of others that have employed the models of lifestyle audits s (LSAs) and LSAs terminologies like net worth analysis, criminological profile, offender profiling evidence, bank deposits analysis to examine the FAC and other white collar crimes were not conducted in Nigeria but in the foreign countries like South Africa, Kenya, USA. Again, those reviewed related studies like Izedonmi and Ibadin (2012), Anyaduba and Modugu (2013); Gbegi and Okoye (2013); Akenbor and Ironkwe (2014); Ernest. Gabriel, Masoyi and Zachariah (2014); Mohammed and Peter(2016); Adeniyi (2016); Appah and Ogiriki (2018) among others that were conducted in Nigeria only employed variables like forensic accounting, forensic investigation, forensic accounting and auditing techniques, removal of immunity clause and financial investigation apart from lifestyle audits to examine curbing of corruption, detection of frauds and other financial crimes (FCs). This study is therefore set to fill the gaps by examining lifestyle audits and fighting against corruption with evidence from Nigeria. Specifically, the study investigated the viability of net worth analysis as a tool for fighting corruption and also examined the viability of bank deposits analysis as a tool for fighting corruption. This study could appeal to government, educational regulators and the accounting professional bodies on the need to incorporate the studies of lifestyle auditing into the educational curricula in 
Nigeria and other countries that are yet to adopt it. The outcomes of this study could also guide the government and business owners all over the world on how to safeguard their assets from corrupt people. The exploration of LSA is could be an add value to the existing bodies of knowledge in the field of accounting and auditing across the globe.

\subsection{Literature Review}

\subsection{Lifestyle Audit and Fighting against Corruption}

Government at all levels, anti-graft agencies and the accounting professional bodies need to give lifestyle audits (LSAs) a chance as a new viable tool that can fight against corruption (FAC). Corruption is the use of entrusted public powers for private purposes (Stober, 2019). Corruption is the use of public offices for personal gain (Ngumbi, 2019). Corruption by public officials amounted to stealing from the poor (Tim \& Sam, 2016). Conducting a LSA during the investigation into financially related offences is imperative (Kola, 2018). Application of LSAs as a mechanism can expose the suspects' corrupt practices and other illicit activities. Corruption takes different forms such as bribery, extortion, misappropriation or diversion of public assets for personal use, patronage, nepotism, favouritism and conflicts of interest. Bribery is the something offered in cash or kind or gift as an inducement to procure illegal or dishonest action (Sam et al., 2016). Extortion is the opposite of bribery and it happens when money is demanded rather than offered in order to secure a particular outcome (Ngumbi, 2019). Nepotism is an undue favour from holder of patronage to relatives (Kola, 2018). Misappropriation is the use of other's money or properties for one's own use (Stober, 2019). Patronage is a wrong support/encouragement given by patron and thus misusing of position (Stober, 2019). Favouritism is an unduly preferring one to other (Stober, 2019). Fighting the menace of corruption worth continuous debate among the researchers and academicians as the rate of its occurrence has not globally shown any decline. Efforts should not be relented in wagging wars against corrupt government officers and political office holders through LSAs. During the investigation of corruption, the suspects under investigation may exhibit a lifestyle or net worth beyond their known means of income (Kola, 2018). There are obvious lifestyle changes that may be an indication of corrupt practice. Lifestyle analysis can expose the corrupt politicians and big spenders among top government officials (Ngumbi, 2019).

The objective of lifestyle audits (LSAs) exercise is to identify cases of unreported income, unjust self enrichment and prevents likelihood of corruption (Munjeyi \& Munjuru, 2018). Kola (2018) described a LSA as a financial investigation conducted to determine if a person's living standard is consistent with his reported income. LSA is a test that determines if the lifestyle an individual is living commensurate with his known income stream (Ngumbi, 2019). LSA is an investigation to estimate the known living expenses of the suspect, such as mortgage payment, groceries, insurance, healthcare costs, automobile fuel and the comparison of this wealth with his reported income to determine his illegal lifestyle changes (Gillespie, 2014). However, Daysh et al. (2000), Ainsworth (2001), Bekerian et al. (2007), Jason (2007), Norbert (2007), Andre (2009) Sam et al. (2016) identified some terminologies that can be used to describe lifestyle audits such as criminological profiling or offender profiling (OP), net worth analysis (NWA), analysis of bank statements or bank deposit analysis (BDA) among other. However, this study used three independent variables of NWA and BDA against the fighting of corruption.

Net worth analysis (NWA) is a frequently used lifestyle audit of circumstantially proving income from an unknown or illegal source (Daysh et al., 2000). The basic component in computing a net worth is to establish a starting point called base year' as the point of reference which is the "year prior to the year in which the alleged illegal activity started for comparison to subsequent years' net worth changes" (Andre, 2009). The base year stands as the year the investigator believes the suspects would have maintained a 'normal' lifestyle without illicit income (Andre, 2009). The investigator will then develop a financial profile for the "base yea" and each of the "consecutive years" during which the suspects have gained from illegal income, the net worth analysis formula will then be applied (Andre, 2009). Summarily, NWA is estimated thus: Base year net worth (NW) minus prior years' NW equal to increase or decrease in the NW from previous years plus known expenses equal to total NW increase or decrease minus reported income equal to unreported income. The NW is total assets less total liabilities. It should be noted that the examples of non-deductible expenditures to be added include personal living expenses, income tax payments, non-deductible portion of capital losses, losses on sale of personal assets and gifts made. The income not taxable to be deducted include tax-exempt interest, computed depreciation, nontaxable pensions, nontaxable insurance proceeds, gifts received, inheritances, veterans' benefits, dividend exclusions and excludable sick pay. Adjustments are to be made for the living expenses to arrive at income by subtracting total net worth increase today from reported income such as salary, interest, dividends and commission to arrive at unknown or illegal income (Andre, 2009). There should be computed reserves for depreciation/amortization per return (Andre, 2009). Therefore, NWA is a LSA that can estimate unreported income of the suspects. Thus this study hypothesized that:

1. $\mathrm{H}_{0}$ : Net worth analysis is not a viable tool for fighting against corruption. 
Bank deposit analysis (BDA) is a lifestyle audit of detecting illegal income (Jason, 2007). In the event where the bank deposits are higher than the income reported, the difference is the income not reported (Jason, 2007). BDA has been applied by South African government in computing undeclared taxable income (Andre, 2009). The analysis of bank account statements is a fundamental step in using the information in a bank deposit to obtain evidence of illegal financial deals (Jason, 2007). South Africa government used eight stages process of analyzing bank deposits "Tesch's eight-step process" which include "collation of the information in the bank statements into an electronic format; identification of significant payees and depositors; compilation of summary statements which summaries the information; examining the information in the bank account statements over a period of time to produce a time series analysis; drawing up various charts to visually display the information; examining the bank statements and the results of the previous stages of the analysis process to determine the patterns of activity with regard the accounts to determine any unusual activity and reporting on the findings of the analysis of the bank account statements, either by way of an affidavit, if the analysis is going to be used as evidence, or by way of a report, if the analysis is going to be used for intelligence purposes" (Jason, 2007). In summary, Bank deposit analysis is estimated as follow: Total business cash expenses plus all banks deposits plus all business cash expenses plus all personal expenses paid in cash plus all capital item bought in cash/by cheque plus cash accumulations not deposited in any banks equal to total estimated cash receipts minus gross cash receipts/total gross income/reported income =equal to *unreported income/illegal income However, all the deposits in the suspect's bank accounts will be added to arrive at the gross bank deposits. The expenses made in cash are added to get gross cash total. The net taxable deposits must be equal to the reported gross income. The amount will later be reduced relevant deductable and tax exempted expenses. The figure to be arrived at is considered to be "corrected income." It is then compared with the income reported by the suspect on his return. Thus this research work hypothesized that:

2. $\mathrm{H}_{0}$ : Bank deposits analysis is not a viable tool for detecting corruption.

\subsection{Theoretical Review}

The study is anchored on Prebendalism theory of corruption (PTC) in Adamu (2013) propounded by Professor Joseph Richards of North-Western University in the United States of America. Professor Richard's PTC described that the reasons for the prevalence of corruption is the possibility that the public officers and political office holders in position of authorities might easily enforce the powers or rights they possess to control and use the resources, offices and influences in their possession as if the things belong to them (Adamu, 2013). The PTC explained further that "the new form of inheritance phenomena that posed treat on the public trust as a prebend is that, those who are in charge of public resources behaves as if the resources in their cares are their lost property to be reacquired, owned and dispensed at the expense of citizenry and the public interest at large" (Adamu, 2013). PTC described the incidence that might give rise to corruption in any human organizations by identifying some factors that directly give room to the occurrence of the so-called corruption like self-centre, possession of powers and opportunities to be in authority. The theory made an assumption that in the absence of the aforementioned those factors and many others, corrupt practices could be impossible (Adamu, 2013). Thus the PTC is a logical explanation of the causes and solutions to corruption in Nigeria and elsewhere in the wolrd (Adamu, 2013). However, based on the views of Professor Joseph Richard and Adamu (2013 ), it is apparent that the selfishness and opportunities of those who found themselves in the corridor of power that pave ways to the prevalence of corrupt practices and other financial crimes by diverting and misappropriating the resources belong to every other people. Therefore application of Prebendalism theory of corruption suit the purpose of this study

\subsection{Empirical Review}

Kola (2018) examined "Unmasking lifestyle audit (LSA) as a proactive mechanism to root out corruption: the case of South Africa". The study adopted an exploratory research design, and employed content analysis and logistic regression to analyze data gathered. The study concluded that LSA "is an anti-corruption tool that can root out corruption before it turns to endemic". Ngumbi (2019) investigated "viability of LSA as an anticorruption strategy in Kenya: a critical assessment of the policy, legal and administrative framework". A descriptive approach was adopted and secondary data was collected and analyzed using content analysis. The study found that "provisions relating to LSAs under the laws of Kenya are too weak to make LSAs an effective tool against the runaway corruption in the country". The study concluded that "Kenya's legal and administrative frameworks for LSAs are insufficient and not proportional to the nature and extent of corruption in Kenya". Jason (2007) conducted a study on the "analysis of bank account statements (BASs) to establish evidence of illicit financial activity in South Africa". The study adopted exploratory research design." Tesch's eight-step process" was used to analyze data. Findings from the study showed that "there was no consistent financial analysis methodology addressing BASs currently being employed in South Africa". The study concluded that the analysis process synthesized by this research "Tesch's eight-step process" should be made available to 
investigators in South Africa for use in analyzing bank account statements especially with regard to investigations involving illicit financial activities"

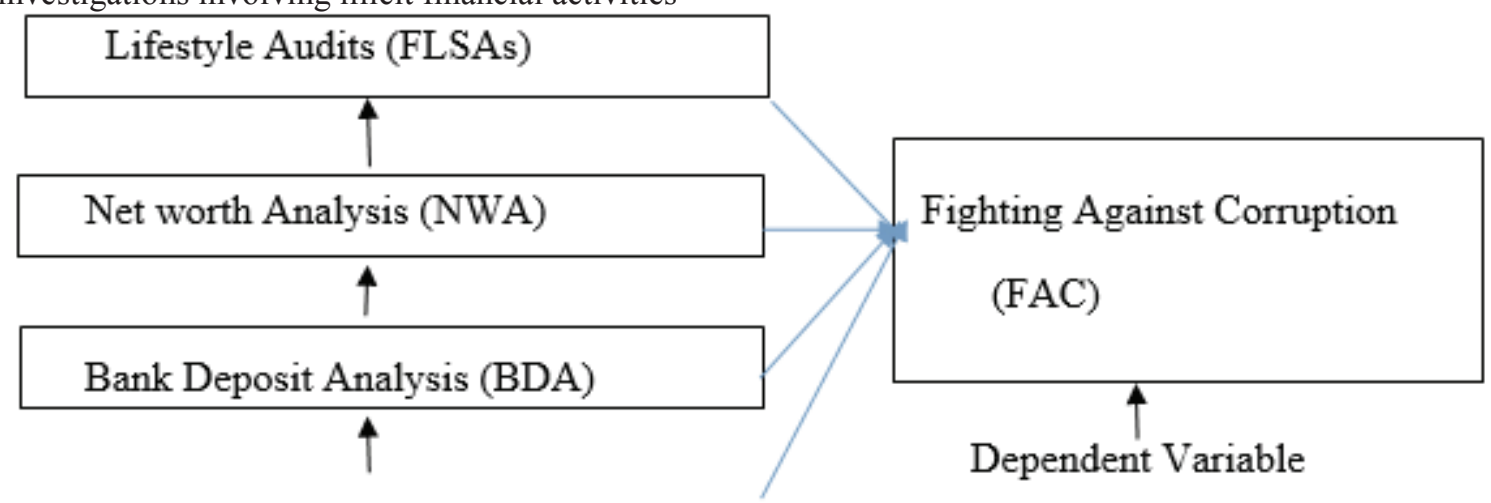

\section{Independent variables}

Figure 1: Conceptual Model of the Study

Source: Author's Design (2020)

The conceptual model of this study in figure 1 described a relationship between the three explanatory independent variables of NWA, BDA, the proxies for LSAs and the dependent variable of FAC.

\subsection{Methodology}

This study investigated the effectiveness of lifestyle audit as a mechanism of fighting against corruption. This study's population is made up of 868 auditors and accountants in the services of eight selected private and public organizations in Osun State of Nigeria. A survey research design was adopted and primary data was collected because the studies that examined LSAs to FAC are rear and yet unexplored in Nigeria justified the use primary data to conduct a field survey to obtain direct information from the respondents. Purposive sampling technique was employed to draw the samples size of 400 from the study population using "Taro Yamern model' estimated at $868 / 868(0.05)^{2}=400$.During the sampling, we ensure that only those who have auditing and accounting experience were given consideration. Of the total numbers of 400 copies administered questionnaires, 241 were returned valid and used repressing 60\%. The selected organizations, their study population, sample size and valid sample taken were as follow: Osun State Auditor General office (279)/110*94, Accountant General Office $(164) / 76 * 49$, Ministry of Finance $(233) / 79 * 09$, Minist ry of Commerce and Industry (75)/74*67, Osun Internal Revenue office $(104) / 53 * 14$, and for the three sampled private organizations namely Obelawo Group of Company (06)/3*3, Twins Brothers limited (3)/1*1 and Prince-cut Hotel (4)/4*4. We should note thast the study population of the accountants and auditors were put in bracket ( ), sample size were preceded with slash / and the valid sample taken with asterisk *. The questionnaire was designed with a 3-likert scale of agree $(A-3)$, disagree $(D-2)$ and neutral $(\mathrm{N}-1)$ to obtain responses from the respondents. The validity of the instrument was determined using expert opinions in the field of accounting. This study employed Cronbact Alpha coefficient reliability test that yielded a stability coefficient of $98.5 \%$ as showed in table 1 . The data gathered was analyzed using descriptive and inferential statistics like frequency charts, correlation analysis and other regression models with the aid of Statistical Packages for Social Sciences (SPSS) version 20 tested at 1\% level of significant. A descriptive statistics like frequency charts was used to describe the selected organizations based on their number of respondents, while the inferential statistical tools such as general linear and multiple regression models were used to determine the relationship among the variables.

Table 1`Cronbact Alpha Reliability Test

\begin{tabular}{cc}
\hline Cronbach's Alpha & Number of Items \\
\hline 0.985 & 04 \\
\hline
\end{tabular}

Source: Author's Computation (2020)

Table 1 showed the result of reliability test conducted to establish decision on the goodness or otherwise of the instrument (Questionnaire). The result of the test of $98.5 \%$ above the recommended minimum alpha value of $70 \%$ (George \& Mallery, 2003) confirmed that the instrument is effective and good for this research work

\section{Model Specification}

This study adopted multiple regression model used by Anuolam, Ekeke and Onyema (2016) who investigated "Forensic accounting and financial crimes: adopting the inference, relevance and logic solution approach". The 
study employed fraudulent practices (FDP) as the dependent variable forensic accounting services (FAS), forensic accounting validation (FAV) and forensic accounting practices (FAP) as the three explanatory independent variables. The model is as follow:

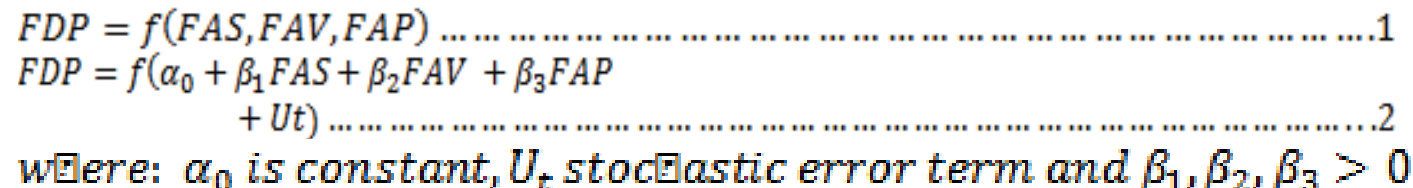

Anuolam et al. (2016)'s model was adapted and modified as follow: Both explanatory independent variables and dependent variable used by Anuolam et al. (2016)'s were replace with this study' variables using fighting against corruption (FAC) as the dependent variable and comparative net worth analysis (CNWA), and bank deposit analysis (BDA) as the explanatory independent variables, Ut, the stochastic error term. This study's model is specified below:

$\mathrm{FAC}=f(\mathrm{NWA}, B D A)$

\section{FAC}

$=f(\beta 0+\beta 1 \mathrm{NWA}+\beta B D A$

$+U t)$

Where $:$ FAC $=$ fighting against corruption, $\quad$ NWA = net worth analysis,

$B D A$

$=$ bank deposit analysis, $\beta 0$ is constant, $U t$ stochastic error term and $\beta 1, \beta 2$, are parameters /coefficiens.

Table 2 Identification of Variables

\begin{tabular}{|l|l|l|l|}
\hline Variables & Variable Proxies & Proxy's Sources & Measurement \\
\hline Independent Variable & $\begin{array}{l}\text { Net worth analysis } \\
\text { Lank deposit analysis }\end{array}$ & $\begin{array}{l}\text { Exley et al., etc } \\
\text { Jason (2007) }\end{array}$ & Questionnaire \\
\hline Dependent Variable & \multicolumn{3}{|l|}{} \\
\hline Corruption & $\begin{array}{l}\text { Bribery } \\
\text { Extortion } \\
\text { Misappropriation of assets }\end{array}$ & $\begin{array}{l}\text { Sam et al. (2016) } \\
\text { Ngumbi (2019) Stober } \\
(2019)\end{array}$ & Questionnaire \\
\hline
\end{tabular}

Source: Author's Design (2020)

Table 2 showed the independent and dependent variables, their proxies and proxy's sources as measured by using questionnaire.

\subsection{Empirical Findings}

4.1 Inferential Statistics

This section analyzed the general linear and regression models like between-subject factors, correlation, model summary, analysis of variances (ANOVA) and regression coefficients used for data analysis.

\subsubsection{General Linear Model}

Table 3: Between-Subjects Factors

\begin{tabular}{llll}
\hline & & Value Label & $\mathrm{N}$ \\
\hline \multirow{3}{*}{ Fight Against Corruption } & 1.00 & Neutral & 15 \\
& 2.00 & Agree & 60 \\
& 3.00 & Disagree & 166 \\
\hline
\end{tabular}

Source: Author's Computation (2020)

Table 3 showed the results of between-subjects factors of the liket-scale distribution where $166(69 \%)$ of respondents disagreed with the hypotheses that LSAs as a viable tool to FAC in Nigeria, while $60(25 \%)$ of them agreed and $15(6 \%)$ of them played neutral. 


\subsubsection{Regression Models}

Table 4: Model Summary

$\begin{array}{lllll}\text { Model } & \text { R } & \text { R-Square } & \text { R-Square Adjusted } & \text { Estimate of Standard Error }\end{array}$
$10.0 .975^{\mathrm{a}}$
0.951
0.951
0.13437

Note: a. Predictors: (Constant), Net worth analysis, Bank deposit Analysis

Source: Author's Computation (2020)

Table 4 showed the result of regression model summary where coefficient of determination $(\mathrm{R}$-square $)=$ 97.5\%. This means the explanatory independent variables of NWA and BDA are explained by $97.5 \%$ of the variation in the dependent variable of $\mathrm{FAC}$ and the remaining $2.5 \%$ is explained by other factors outside the model and error term. Thus, null hypotheses 1,2 and 3 are rejected. That is, NWA and BDA are among the effective tools that can be used to fight and expose corruption.

\begin{tabular}{llllll}
\multicolumn{1}{l}{ Table 5: Analysis of Variances (ANOVA) } \\
\hline Model & Sum of Squares & df & Mean Square & F \\
\hline & Regression & 81.232 & 3 & 27.077 & 1499.786 \\
& $\begin{array}{l}\text { Residual } \\
\text { 1 }\end{array}$ & 4.152 & 230 & .018 & \\
& Total & 85.385 & 233 & &
\end{tabular}

Notes: a. Dependent Variable: Fight Against Corruption

b. Predictors: (Constant), Bank deposit Analysis, Net worth Analysis

Source: Author's Computation (2020)

The result of ANOVA in able 5 where p-value of $0.000<0.01$ at $95 \%$ level of significant is an indicated a significant relationship between FAC and NWA, BDA in Nigeria since the p-value $<0.01$.

Table 6: Correlation Analysis

\begin{tabular}{cccc}
\hline & FAC & NWA & BDA \\
FAC Pearson Correlation & 1 & $971^{* *}$ & $959^{* *} \cdots$ \\
Sig.(2-tailed) & 000 & 000 & 000 \\
N & 234 & 234 & 234 \\
NWA Pearson Correlation & $.971^{* *}$ & 1 & $961^{* *}$ \\
Sig.(2-tailed) & 000 & 000 & 000 \\
$\quad$ N & 234 & 234 & 234 \\
BDA Pearson Correlation & $.959^{* *}$ & $.961^{* *}$ & 1 \\
Sig.(2-tailed) & 000 & 000 & 000 \\
$\quad \mathrm{~N}$ & 234 & 234 & 234
\end{tabular}

Notes: **. Correlation is significant at the 0.01 level $(2$ tailed $) . F A C=$ fight against corruption, NWA $=$ comparative net worth analysis, $\mathrm{BDA}=$ bank deposits analysis .

Source: Author's Computation (2020)

The correlation analysis results of 0.971 and 0.959 between FAC and NWA and between FAC and BDA in table 6 showed strong positive relationships. Also, p-value of $0.000<0.01$. Thus, the null hypotheses which said that net worth analysis and bank deposit analysis are not the effective tools for fighting corruption are rejected meaning that lifestyle audits are viable tools for fighting against corruption.

Table 7 Coefficients ${ }^{\text {a }}$

\begin{tabular}{|c|c|c|c|c|c|}
\hline \multirow[t]{2}{*}{ Mode } & \multicolumn{2}{|c|}{$\begin{array}{l}\text { Unstandardized } \\
\text { Coefficients }\end{array}$} & \multirow{2}{*}{$\begin{array}{l}\text { Standardized } \\
\text { Coefficients } \\
\text { Beta }\end{array}$} & \multirow[t]{2}{*}{$\mathrm{t}$} & \multirow[t]{2}{*}{ Sig. } \\
\hline & B & Std. Error & & & \\
\hline (Constant) & -0.113 & 0.048 & & $0-2.346$ & 0.020 \\
\hline Net worth & 0.684 & 0.063 & 654 & 10.795 & 0.000 \\
\hline 1 Bank deposit & & & & & \\
\hline Analysis & 0.357 & 0.057 & 0.334 & 6.222 & 0.000 \\
\hline
\end{tabular}

Note: a. Dependent Variable: Fight Against Corruption

Source: Author's Computation (2020)

The results in table 7 explained the equation: $\mathrm{FAC}==0.113+\beta_{1} 0.684+\beta_{2} 0.0 .357+-\beta_{3} 0.005+U_{t}$. By the 
interpretation, it means a unit increase in the application of NWA and BDA will lead to additional increase in the effectiveness of lifestyle audits to detect, expose and fight against corruption.

\subsection{Discussion of Empirical Results}

The tested null hypotheses 1 and 2 using different statistical models revealed association between explanatory variables of net worth analysis, bank deposits analysis, proxies for independent variable of lifestyle audits and the dependent variable of the fight against corruption, The result of between-subject factors in table 3 revealed that 159 respondents disagreed with the first null hypothesis saying that net worth analysis is not a viable tool for fighting against corruption, and also disagreed with the second saying that bank deposit analysis is not a viable tool for fighting against corruption as the majority of the respondents agreed while only view of them remained neutral. This indicated the rejection of above mentioned the two null hypotheses. In table 4 as well, model summary result with R-square of $97.5 \%$ is a indicated that $97.5 \%$ of the variation in FAC can explain the explanatory independent variables of NWA, BDA while the remaining $2.5 \%$ is described by other factors outside the model and error term. Therefore, the two null hypotheses were aalso rejected. The same outcome was obtained when the result of ANOVA in able 5 showed a p-value of $0.000<0.05$ indicating strong relationship between FAC and NWA, BDA, and FAC. Also, correlation results of $(0.971,0959,0.917)$ with a p-value of $0.000<0.01$ in table 6 showed strong correlation among the variables. Thus, the the null hypotheses were also rejected. More so, the ANOVA result in table 7 generated similar results with a p-value of $0.000<0.01$. The result in table 8 also indicated that as the practical application of LSAs increases by a unit increase, the rate of corruption will decrease proportionally. Conclusively, The tested two null hypotheses $\left(\mathrm{H}_{0}\right)$ were absolutely rejected paving way to alternative hypotheses $\left(\mathrm{H}_{1}\right)$ to be accepted That is, net worth analysis is a viable tool for fighting against corruption. Also bank deposits analysis is a viable tool for fighting against corruption. However, findings from this study confirmed that lifestyle audits (LSAs) can be applied to fight against corruption in Nigeria and other part of the world as the large proportion of respondents embraced the application of LSAs in waging wars against corruption and other financial crimes in the country and across the globe.

\section{Conclusion}

Corruption is remained the enemy of any economy and should be absolutely arrested through the lifestyle audits (LSAs) as the results of research work showed a complete demand for the application of LSAs in Nigeria and other countries around the world. This study's results agreed with the results of the studies conducted by Kola (2018) who investigated "Unmasking lifestyle audit (LSA) as a proactive mechanism to root out corruption: the case of South Africa" where there-in found that "Lifestyle audit is an anti-corruption tool that can root out corruption before it turns to endemic". For countries around the world including Nigeria to effectively apply the new audit mechanism of corruption fighter and other FCs like money laundering and tax evasion, government needs to amend the existing administrative and legal frameworks to give lifestyle audits a chance to be operated effectively and ne able to investigate, expose, arrest, detain and make a trial of suspects for corruption in Nigeria and all over the world. Those existing laws of country that may what to operate LSAs should be amended in a way that will cause the reports generated from the LSAs conducted to be admitted in the court of laws and to give the lifestyle auditors of governments to court recognition. Ngumbi (2019) who examined the "Viability of LSA as an anti-corruption strategy in Kenya: a critical assessment of the policy, legal and administrative framework" confirmed these suggestions when the study found that "legal provisions relating to LSAs under the laws of Kenya are too weak to make lifestyle audit an effective tool against the runaway corruption in the country". This impression should open a world campaign to the concerned citizen, anti-graft agencies and governments to embrace the practices of LSAs. LSAs are a new global concept in the field of accounting and auditing professions that are yet to gain world-wide popularity as the only few countries and researchers are aware of its existence.

\section{REFERENCES}

Adamu, A. (2013, December 27). On ending prebendalism. Daily Trust. Retrieved from ttps://www.google.com/search?q=On+ending+prebendalism $\% 2 \mathrm{C} \& i e=u t f-8 \& o e=u t f$ $8 \%$ client $=$ firefox-b-ab

Adeniyi, A. A., (2016). Forensic auditing and financial fraud in Nigerian Money Deposit Banks: European Journal of Accounting, Auditing and Finance. 4(8), 1-19.

Ainsworth, B. P., (2001). An Offender Profiling and Crime Analysis Devon, Willan Publishing.

Akenbor, C. O. \& Oghoghomeh, T., (2013). Forensic auditing and financial crime in Nigerian banks: A proactive. The Business \& Management Review 4(2).

Akenbor, C. O. \& Ironkwe, U. (2014). Forensic auditing techniques and fraudulent practices of public institution in Nigeria: Journal of Modern Accounting and Auditing, 10 (4). 451 - 459.

Ali, A. A., Ali, A. Y. S. \& Dalmar, M. S. (2018). The impact of tax revenues on economic growth: a time series 
evidence from Kenya, Academic Research International, 9, 163 -170.

Anuolam, O. M, Ekeke, U. \& Onyema, T. E. (2016). Forensic accounting and financial crimes: Adopting the inference, relevance and logic solution approach. West African Journal of Industry and Academic Research, $17,126-132$.

Andre, E. B. (2009). The net worth method as a technique to quantify income during investigation of financial crime: A thesis submitted in part fulfillment of the requirements for the Degree of Magister Technologies in the subject of Forensic Investigation in the University of South Africa, Johanessseburg, University of South Africa Press.

Anyaduba, J. O. \& Modugu, K. P. (2013). Forensic accounting and financial fraud in Nigeria: an Empirical Approach: International Journal of Business and SocialScience, 4(7).

Appah, E. \& Ogiriki, T. (2018). Forensic accounting \& auditing techniques on public sector fraud in Nigeria: International Journal of African and Asian Studies, 27, 7 -16.

Bekerian, D. A. \& Jackson, J. L. (2007). Offender profiling: theory, research and practice. Chichester: Wiley, USA

Ernest, E. I., Gabriel, A. O., Masoyi, A. D., \& Zachariah, P., (2014). Application of forensic auditing in reducing fraud cases in Nigeria Money Deposit Banks: GlobalJournal of Management and Business Research: D accounting and Auditing 14(3), 32-41.

Daysh, R. \& Exley, A. (2000). Net Worth Analysis: Blunt instrument can aid investigations: The White Paper, November/December, 2000.

George, D. and Mallery, P. (2003) SPSS for Windows Step by Step: A Simple Guide and Reference, 11.0 update. Boston: Allyn \& Bacon.

Gillespie, R. T., (2014). The Best Practice Applied By Forensic Investigators in Conducting Lifestyle Audits on White Collar Crime Suspects. Johanesseburg, University of South Africa Press.

Gbegi, D. O. \& Okoye, E. I. (2013). Forensic Accounting: A Tool for Fraud Detection and Prevention in the Public Sector: International Journal of Academic Research in Business and Social Sciences, 3(3), 22226990.

Izedonmi, F. \& Ibadin, P. O. (2012). Forensic accounting and financial crime: adopting the inference, relevance and logic solution approach: An International Multidisciplinary Journal, Ethiopia. 6(27), 125 139..http://dx.doi.org/10.4314/afrrev.v6i4.9

Jason, J. (2007). The analysis of bank account statements to establish evidence of illicit financial activity . Johanesseburg, University of South Africa Press.

Kola, O. O., (2018). Unmasking lifestyle audit as a proactive mechanism to root out corruption: The case of South Africa. Journal of Legal, Ethical and Regulatory Issues. 22(6), 4-12

Munjeyi, E. \& Mujuru, S. (2018). Is it worth investing in lifestyle audit in Zimbabwe: International Journal of Innovative Research in Science, Engineering and Technology. 1(8), 7-18. https://www.researchgate.net/publication/341286078

Mohammed, U.B. and Peter, K.N. (2016). Immunity clause and white collar crimes in Nigeria:acallforthewithdrawalofimmunityclause.JournalofResearchin Humanities and Social Science, 4(9),60-65.

Norbert, E. (2007). The use of offender profiling evidence in criminal cases, Golden Gate University, School of Law, San Francisco, California.

Ngumbi E. M. (2019). Viability of lifestyle audits as an anti-corruption strategy in Kenya: a critical assessment of the policy, legal and administrative framework. AThesis submitted to the University of Nairobi Law School in part fulfillment of the requirements for the award of the Degree of Master of Laws (LLM), University of Nairobi, Kenya.

https://www.researchgate.net/publication/341286078

Sam K. \& Tim, V. E. (2016). A criminological profile of white collar crime: The Journal of Applied Business Research. 32(1). 1-142.

Stober, E. O. (2019). Nigeria's corruption score card, Management Dynamics in the Knowledge Economy,7 (2), $165-182 ; 10.25019 / \mathrm{mdke} / 7.2 .03$. 